\title{
Quality of life of people who practice ballrom dance
}

\section{Qualidade de vida dos praticantes de dança de salão}

\section{Zenite Machado ${ }^{1}$ \\ Gabriella Roberta dos Santos ${ }^{2}$ \\ Adriana Coutinho de Azevedo Guimarães ${ }^{3}$ \\ Sabrina Fernandes ${ }^{4}$ \\ Amanda Soares 5}

\begin{abstract}
1. Departamento de Educação Física do Centro de Ciências da Saúde e do Esporte da Universidade do Estado de Santa Catarina, Brasil; Doutora em Motricidade Humana pela Faculdade de Motricidade Humana da Universidade Técnica de Lisboa, Portugal.

2. Centro de Ciências da Saúde e do Esporte, Universidade do Estado de Santa Catarina, Brasil. 3. Departamento de Educação Física, Centro de Ciências da Saúde e do Esporte, Universidade do Estado de Santa Catarina, Brasil; Curso de Doutorado na Faculdade de Motricidade Humana, Universidade Técnica de Lisboa, Portugal. 4. Serviço Social da Indústria - SESI. Universidade Federal de Santa Catarina, Programa de Pós Graduação em Atividade Física e Saúde. Santa Catarina, Brasil.

5. Departamento de Fisioterapia, Instituição de Ensino Superior e Departamento de Educação Física, Faculdade Porto das Águas. Mestre pela Universidade Federal de Santa Catarina, Programa de Pós Graduação em Atividade Física e Saúde. Santa Catarina, Brasil.
\end{abstract}

\section{ENDEREÇOPARACORRESPONDÊNCIA}

\section{Zenite Machado}

Rua João de Deus Machado, 74 - Apto 103 Florianópolis, SC

88036-510

zenite13@yahoo.com.br

$\begin{array}{lr}\text { - Recebido: } & 30 / 08 / 2011 \\ \text { - Re-submissão: } & 11 / 10 / 2011 \\ \text { - Aceito: } & 15 / 10 / 2011\end{array}$

\begin{abstract}
The transversal cut study aimed to investigate the quality of life in ballroom dance practitioners in Florianopolis - SC. The sample was composed of 402 subjects aged 21 to 83 years, who use to attend ballroom dance classes. In order to perform the study, a questionnaire was carried out, which consists of four parts: personal identification, socioeconomic status, dance practice and quality of life (assessed by means of the WHOQOL BREF Questionnaire). After carrying the study out it is observed that ballroom dance is searched by individuals in different ages, particularly the younger unmarried ones belonging to an upperclass. Ballroom dance seems to be an instrument for improving/managing quality of life on the four different domains (physical, psychological, social and environmental). By means of Spearman's correlation the quality of life domain are associated to certain characteristics from which the most relevant were the participation in another activity (physical, psychological, social and environmental), the age (physical and environmental), the practice time (physical and social), and aspects of ballroom dance practice (physical). Furthermore, associations between physical, social, and environmental domains were found. The psychological domain is associated with the social one, and the environmental, is also associated with the psychological and social domains.
\end{abstract}

Keywords: Dance; Quality of life; Physical activity.

\section{Resumo}

O estudo de corte transversal teve como objetivo investigar a qualidade de vida dos praticantes de dança de salão em Florianópolis - SC. A amostra foi composta de 402 sujeitos com idades entre 21 e 83 anos, freqüentadores de aulas de dança de salão. Para a realização do estudo foi utilizado um questionário composto por quatro partes: identificação pessoal; situação sócio-econômica; prática da dança e qualidade de vida (mensurada por meio do Questionário WHOQOL BREF). Após a realização do estudo observa-se que a dança de salão é procurada por indivíduos em diferentes idades, mas congrega preferencialmente os mais jovens, não casados e pertencentes a classes socioeconômicas elevadas. A dança de salão parecer ser um instrumento para a melhoria/ manutenção da qualidade de vida para os quatro domínios (físico, psicológico, social e ambiental). Por meio da correlação de Spearman os domínios da qualidade de vida associam-se a algumas características nos quais as mais relevantes foram a participação em outra atividade (físico, psicológico, social e ambiental), a faixa etária (físico e ambiental), o tempo de prática (físico e social) e aspectos da prática de dança de salão (físico). Foram verificadas ainda associações entre o domínio físico e o social e domínio ambiental. O domínio psicológico associa-se com o domínio social e o domínio ambiental, por sua vez, associa-se ainda com o domínio psicológico e com o domínio social. Palavras-chave: Dança; Qualidade de vida; Atividade física. 


\section{INTRODUCTION}

Quality of life (QoL) has been much discussed over recent years because there has been great concern regarding health and health risk problems that are made worse through excesses constantly imposed on the body. These excesses may include stress, poor posture, early wear and tear on joints, sedentarism, inadequate diets and consumption of alcohol and other drugs that cause acceleration of chronic non-transmissible diseases.

QoL has been defined by the QoL Group of the World Health Organization as "individuals' perception of their position in life, in the context of the culture and value systems in which they live and in relation to their goals, expectations, standards and concerns". Thus, QoL differs from person to person, but its general concept involves: state of health, longevity, work satisfaction, salary, leisure, family relationships, disposition, pleasure and even spirituality, and it falls within the sphere of physical, psychological, social and environmental wellbeing ${ }^{1}$.

Variables such as practices of regular guided physical activity reduce the risks of cardiovascular diseases, diabetes, hypertension and some types of cancer, and improve body weight control and blood glucose level maintenance ${ }^{2}$, as well as constituting an important component in maintaining QoL. However, physical activity practice along is insufficient to maintain good QoL and wellbeing. Thus, in addition to being aware of the desirability of physical activity, individuals need to be included within their social, intellectual and cultural settings ${ }^{3}$.

Within this context, ballroom dancing is a differentiated type of physical activity that brings together these characteristics. Practicing this activity influences the psychomotor, socioaffective and perceptive-cognitive domains, and is related to improvements in motor coordination, rhythm, spatial perception, development of the musculature and development of self-esteem. It allows people to live together and have greater social relationships, and it breaks down a variety of psychological barriers, especially shyness ${ }^{4-5}$.

Today, although ballroom dancing is far from being fashionable, the media has contributed towards developing this practice, so that it has become something that is talked about ${ }^{6}$. Thus, dancing may stimulate development through action and reflection, thereby reinventing movement that is committed to pleasure of the body and mind, and may promote their growth in different respects and enable them to have better QoL?.

However, it is rare to find any studies in the literature dealing specifically with ballroom dancing in connection with the context of QoL and physical activity. Thus, the intention of the present study was to expand the knowledge of this topic, through the objective of investigating QoL among ballroom dancers at dance studios in Florianópolis, Santa Catarina.

\section{METHODS}

This cross-sectional study was approved by the Ethics Committee for Research on Human Beings of the State University of Santa Catarina on August 18, 2009, under protocol no. 129/09. The population of this study consisted of ballroom dancers of both sexes and a minimum age of 21 years, who were attending at least two sessions a week, each lasting 60 minutes or more, at studios linked to the Santa Catarina Ballroom Dancing Association (ACADS).

Because of the difficulty of obtaining the real size of the population of ballroom dancing students at studios linked to
ACADS caused by high turnover rates, no sample size calculation was established. The sample was constituted in a non-probabilistic manner by convenience, among the participants at 11 dance studios in the greater Florianópolis region, using the inclusion criteria that these individuals needed to: a) be attending ballroom dancing classes; b) have a minimum age of 21 years; c) have been practicing ballroom dancing uninterruptedly for four months or more; d) voluntarily agree to participate in the study through signing a free and informed consent statement; and e) adequately complete the data-gathering instrument. This process resulted in participation by 402 subjects (54.2\% female), of ages between 21 and 83 years.

To conduct the study, a structured self-administrable questionnaire composed of four parts was used:

a) Personal identification: in this section, five questions were asked, relating to sex, age, marital status, profession and participation in any systematic physical activity other than ballroom dancing. The participants' ages were grouped as follows: $\geq 21$ to $29 ; 30$ to $39 ; 40$ to $49 ; 50$ to 59 ; and $\geq 60$ years.

b) Socioeconomic situation, determined according to a questionnaire from the Brazilian Association of Polling Companies $(A B E P)^{8}$, which defines social class according to items possessed and the head of the family's educational level. The resultant classes are A1, A2, B1, B2, C and D. For statistical purposes, the participants' socioeconomic situation was regrouped as: upper class $(A 1+A 2)$, middle class $(B 1+B 2)$ and lower class $(C+D+E)$.

c) Length of dancing practice: in this section, there were six questions asking about how long the participants had been practicing ballroom dancing (in months), whether they had done this before, anywhere other than in the current dance studio, how many times a week they were currently practicing, how long the classes were, what degree of involvement they had with dancing and what reasons they had for doing ballroom dancing.

d) QoL, measured by means of the questionnaire produced by the World Health Organization in Geneva (WHOQOL-BREF). This instrument is composed of 26 questions that take into consideration the 15-day period prior to the assessment. The protocol classifies QoL into the following domains: Domain I - Physical: pain and discomfort, energy and fatigue, sleep and rest, mobility, activities of daily living, dependence on medications or treatment, and capacity for work; Domain II - Psychological: positive thoughts, thinking/learning/ memory/concentration, self-esteem, body image and appearance, negative feelings, and spirituality/religion/personal beliefs; Domain III - Social relations: personal relationships, social support and sexual activity; Domain IV - Environment: physical security and protection, home environment, financial resources, health and social care, opportunities to acquire information and skills, opportunities for and participation in recreation and leisure activities, physical environment (pollution/noise/traffic/climate) and transportation'.

Initially, contacts were made with dance studios with ballroom dancing classes, and the numbers of participants enrolled in the classes were surveyed. At this time, permission to carry out the study on the studio's premises was requested and the time to gather data was arranged. During the visits, the study objectives were explained to potential participants and they were asked to join in. After they had signed a free and informed consent statement, they were given clarifications regarding how to fill out the questionnaires correctly. The investigators were present at all times during the data-gathering process. This was done in July, August and Sep- 
tember, and the questionnaires were answered individually, with guaranteed confidentiality for the responses and for the respondents' identities, in accordance with the recommendations of the World Health Organization and ethical values, respectively.

Lastly, the data were analyzed by means of descriptive statistics (simple and percentage frequencies, means and standard deviations), and by means of inferential analysis, which was done using the SPSS statistical package, version 17.0. The Kolmogorov-Smirnov test was used with a significance level of 0.05 to investigate whether the data shown normal distribution. Because this showed that the data did not have normal distribution, nonparametric tests were used (chi-square test, Kruskal-Wallis test and Spearman correlation), all with a significance level of $95 \%$.

\section{RESULTS}

From the data presented in Table 1, it can be seen that among the 402 ballroom dancers who participated in the survey, 184 (45.8\%) were male and 218 (54.2\%) were female. The lack of significant difference $(p=0.090)$ calculated using the $x^{2}$ test showed that the numbers of men and women were equivalent.

Among the men, $68.5 \%$ were single, and this percentage was greater than the proportion of single women. Single individuals predominated over other categories and this difference was shown to be significant $(p=0.001)$. Both among males and among females, the greatest number of participants were in the age group from 21 to 29 years $(56.0 \%$ of the men and $50.9 \%$ of the women), and the second greatest number of adherents was in the age group from 30 to 39 years $(21.7 \%$ of the men and $22.0 \%$ of the women). In other words, the participants were predominantly in young adult age ranges $(p=$ $0.001)$. The greatest number of participants were in the middle class, of whom 114 (62\%) were male. There was a significant difference in favor of the classes with higher purchasing power $(p=0.001)$.

With regard to physical activities other than ballroom dancing, it was found that $72.3 \%$ of the men and $61.4 \%$ of the women were involved in practicing some other kind of physical activity. Among the men, 24 types of activity were cited, while 20 types were cited among the women. The most frequent types among the men, in decreasing order, were: weight training (31.5\%), soccer (14.7\%), dancing (7.6\%) and walking (7.2\%). Among the women, the types most practiced were: weight training (21\%), dancing (17.4\%), walking (15.8\%) and Pilates (10.5\%). The existence of a significant difference $(p=0.001)$ between the participants and non-participants suggests that ballroom dancing is associated with an active lifestyle.

It was observed that in joining ballroom dancing classes, the subjects did not limit themselves only to the classes, such that $67.9 \%$ of the men and $64.7 \%$ of the females practiced outside of the classes. Taking into account the significant difference that was found ( $p=0.001$ ), it was perceived that through the participants' adherence to ballroom dancing in places other than the regular classroom, such as in dances, parties and other courses, ballroom dancing thus had a major presence in the participants' lives.

In relation to the length of time for which people had been practicing ballroom dancing, it was found that $37.1 \%$ had been doing it for not more than one year. In second place, totaling $29.2 \%$, were those who had been doing it for more than three years, and in third place (21.6\%) were those who had been doing it for one to two years. This general order was reproduced by each sex separately.

The weekly periodicity of ballroom dancing practice ranged from once to seven times a week, but the greatest concentration was a frequency of twice a week $(32.6 \%$ of the men and $42.7 \%$ of the women). Taking into consideration only the less frequent periodicities, i.e. once to three times a week, it was seen that $60.9 \%$ of the men and $79.4 \%$ of the women limited themselves to a maximum of three sessions a week. The existence of a significant difference $(p=0.001)$ between these figures suggests that the men presented greater regularity of practice.

The ballroom dancers spent from 2 to more than 20 hours a week doing this. For both sexes, the most frequent amount of practice per week was two hours (34.8\% of the men and $39.5 \%$ of the women). However, the second most frequent amount of practice among the men was 5 to 10 hours (26.1\%), while among the women it was 2 to 5 hours (33.9\%).

\begin{tabular}{lccccc}
\hline \multirow{2}{*}{ Characteristics } & \multicolumn{3}{c}{ Male } & \multicolumn{3}{c}{ Female } & \multirow{2}{*}{ p value } \\
\cline { 2 - 4 } & $\mathrm{N}$ & $\%$ & $\mathrm{~N}$ & $\%$ & 0.001 \\
Marital status & 126 & 68.5 & 133 & 61.0 & \\
Single & 43 & 23.4 & 48 & 22.0 & \\
Married & 12 & 6.5 & 23 & 10.6 & \\
Divorced & 1 & 0.5 & 5 & 2.3 & \\
Widowed & 2 & 1.0 & 9 & 4.1 & \\
Separated & & & & & 0.001 \\
Age group & 103 & 56 & 111 & 50.9 & \\
21 to 29 years & 40 & 21.7 & 48 & 22.0 & \\
30 to 39 years & 18 & 9.8 & 30 & 13.8 & \\
40 to 49 years & 16 & 8.7 & 25 & 11.5 & \\
50 to 59 years & 7 & 3.8 & 4 & 1.8 & \\
60 years and over & & & & & \\
Social class & 46 & 25 & 48 & 22 & \\
Upper class & 114 & 62 & 147 & 67.4 & \\
Middle class & 24 & 13 & 23 & 10.5 & \\
Lower class & & & &
\end{tabular}




\begin{tabular}{|c|c|c|c|c|c|}
\hline & \multicolumn{2}{|c|}{ Male } & \multicolumn{2}{|c|}{ Female } & \multirow{2}{*}{$\mathrm{p}$ value } \\
\hline & $\mathrm{N}$ & $\%$ & $\mathrm{~N}$ & $\%$ & \\
\hline \multicolumn{6}{|c|}{ Ballroom dancing practice in another environment } \\
\hline No & 59 & 32.1 & 77 & 35.3 & \multirow{2}{*}{0.001} \\
\hline Yes & 125 & 67.9 & 141 & 64.7 & \\
\hline \multicolumn{6}{|c|}{ Length of time practicing ballroom dancing } \\
\hline 4 months to 1 year & 73 & 39.7 & 76 & 34.9 & \multirow{4}{*}{0.001} \\
\hline 1 year to 2 years & 37 & 20.1 & 50 & 22.9 & \\
\hline 2 years to 3 years & 21 & 11.4 & 28 & 12.8 & \\
\hline More than 3 years & 53 & 28.8 & 64 & 29.4 & \\
\hline \multicolumn{6}{|l|}{ Weekly frequency } \\
\hline 2 times & 89 & 50.3 & 140 & 64.3 & \multirow{3}{*}{0.001} \\
\hline 3 and 4 times & 46 & 25 & 47 & 21.5 & \\
\hline 5 or more times & 49 & 26.5 & 31 & 14.2 & \\
\hline \multicolumn{6}{|c|}{ Duration of the sessions } \\
\hline Up to 2 hours & 64 & 34.8 & 86 & 39.4 & \multirow{4}{*}{0.001} \\
\hline 2 to 5 hours & 30 & 16.3 & 74 & 33.8 & \\
\hline 5 to 10 hours & 48 & 26.1 & 36 & 16.8 & \\
\hline More than 10 hours & 42 & 22.8 & 22 & 10 & \\
\hline \multicolumn{6}{|c|}{ Type of involvement with ballroom dancing } \\
\hline Student & 116 & 63.0 & 171 & 78.4 & \\
\hline Teacher & 29 & 15.8 & 14 & 6.4 & \\
\hline $\begin{array}{l}\text { Bursary- } \\
\text { holder/assistant }\end{array}$ & 39 & 21.2 & 33 & 15.1 & \\
\hline
\end{tabular}

Again, there was a significant difference in favor of the men ( $p$ $=0.001$ ). Based on the weekly frequency and the time spent per week, it was seen that the men presented a greater volume of physical exercise practice. In relation to the main motives that led the subjects to enroll in ballroom dancing classes, the factor that was most often cited was that it was a leisure activity (32.9\% of the men and $32.4 \%$ of the women).

From the scores presented by the different age groups and by the sexes, it can be seen that for the four domains, the QoL was generally above average, on the scale of responses (percentages from 0 to 100). On this, scores close to zero can be understood as a poor assessment and scores close to 100 as an excellent assessment.

In interpreting the data in Table 3, it can firstly be hi- ghlighted that in a general manner, the QoL was satisfactory and similar for the two sexes, since no scores of less than 50 were observed, or any significant difference between the four domains. Other than these initial remarks, the domains presented the following decreasing order: social, environmental, psychological and physical domains. Curiously, although ballroom dancing is characterized as a type of physical activity, the physical domain presented the lowest scores $(58.0 \%$ for both sexes).

In relation to QoL in each of the age groups, noteworthy results were obtained, with a trend towards higher scores in older age groups. This is especially relevant considering the linear increase in environmental domain scores with age, which also showed a statistically significant difference $(p=0.038)$,

\begin{tabular}{lccc}
\hline Domains & Male & Female & p value \\
& $\bar{X} \pm$ & $\bar{X} \pm$ & \\
\hline Physical (\%) & $59.08 \pm 10.46$ & $59.08 \pm 8.79$ & 0.773 \\
Psychological (\%) & $66.35 \pm 9.57$ & $67.13 \pm 9.14$ & 0.380 \\
Social (\%) & $77.04 \pm 16.66$ & $77.52 \pm 15.09$ & 0.878 \\
Environmental (\%) & $70.07 \pm 13.48$ & $70.07 \pm 12.47$ & 0.764 \\
\hline
\end{tabular}

\begin{tabular}{lcccccc}
\hline Domains (\%) & $\begin{array}{c}\text { Age group } \\
\text { 21-29 years }\end{array}$ & $\begin{array}{c}\text { Age group } \\
\text { 30-39 years }\end{array}$ & $\begin{array}{c}\text { Age group } \\
\text { 40-49 years }\end{array}$ & $\begin{array}{c}\text { Age group } \\
\text { 50-59 years }\end{array}$ & $\begin{array}{c}\text { Age group 60 } \\
\text { years and over }\end{array}$ & p value \\
\hline Physical & $58.0 \pm 10.3$ & $58.20 \pm 8.7$ & $60.5 \pm 7.9$ & $63.5 \pm 7.3$ & $62.6 \pm 10.0$ & 0.001 \\
Psychological & $66.1 \pm 9.7$ & $67.3 \pm 9.6$ & $68.0 \pm 7.8$ & $67.8 \pm 8.8$ & $65.1 \pm 5.3$ & 0.662 \\
Social & $76.4 \pm 16.5$ & $77.3 \pm 16.8$ & $80.2 \pm 13.2$ & $78.6 \pm 13.1$ & $76.5 \pm 12.2$ & 0.748 \\
Environmental & $69.0 \pm 12.0$ & $69.6 \pm 13.1$ & $70.3 \pm 13.8$ & $73.5 \pm 14.8$ & $80.1 \pm 11.1$ & 0.038 \\
\hline
\end{tabular}


and a similar trend in the physical domain from the first to the penultimate age group. A significant difference was also seen in this domain $(p=0.001)$.

Although no cause-effect relationship could be established, it was observed that the QoL domains were associated with some of the participants' characteristics and some characteristics of ballroom dancing practice. The physical domain was associated with the participant's age $\left(r=0.171^{* *}\right)$, participation in other types of practice $\left(r=0.194^{* *}\right)$ and length of time practicing ballroom dancing $\left(r=0.129^{* *}\right)$. In other words, the greater the age, existence of engagement in other physical activities and length of time practicing ballroom dancing were, the more the individual had a positive perception of QoL in the physical domain. The psychological domain also presented associations with the subject's participation in other types of practice $\left(r=0.136^{* *}\right)$ and with the time spent on ballroom dancing per week $\left(r=0.435^{* *}\right)$. The social domain was associated with the subject's participation in another type of practice $\left(r=0.157^{* *}\right)$ and with the length of time practicing ballroom dancing $\left(r=0.154^{* *}\right)$. Lastly, the environmental domain was positively associated with the age group $\left(r=0.107^{*}\right)$, participation in other types of practice $\left(r=0.209^{* *}\right.$ and the participant's socioeconomic class $\left(r=0.287^{* *}\right)$. As can be seen the most important characteristics seemed to be participation and QoL domains

\begin{tabular}{|c|c|c|c|c|c|c|c|c|c|c|c|}
\hline & I & II & III & IV & $\mathrm{V}$ & VI & VII & VIII & IX & $\mathrm{X}$ & $\mathrm{XI}$ \\
\hline I & - & & & & & & & & & & \\
\hline II & $\stackrel{n}{0}$ & - & & & & & & & & & \\
\hline III & ठ̊. & $\frac{\text { Oे }}{\stackrel{*}{0}}$ & - & & & & & & & & \\
\hline IV & $\stackrel{m}{\tilde{o}}$ & $\begin{array}{l}0 \\
0 \\
0\end{array}$ & $\begin{array}{l}0 \\
\stackrel{0}{0} \\
0\end{array}$ & - & & & & & & & \\
\hline $\mathrm{V}$ & $\begin{array}{l}\infty \\
\stackrel{0}{0} \\
0\end{array}$ & 苑 & $\begin{array}{l}8 \\
:\end{array}$ & 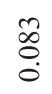 & - & & & & & & \\
\hline VI & $\begin{array}{l}\frac{*}{*} \\
\stackrel{*}{+} \\
+ \\
\end{array}$ & $\begin{array}{l}\frac{*}{*} \\
\infty \\
\infty \\
\dot{0}\end{array}$ & 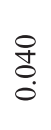 & है & 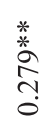 & - & & & & & \\
\hline VII & 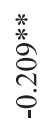 & $\begin{array}{l}\stackrel{*}{*} \\
\stackrel{*}{+} \\
\stackrel{+}{i}\end{array}$ & ڤે. & 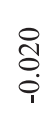 & 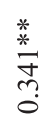 & 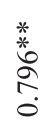 & - & & & & \\
\hline VIII & & $\begin{array}{l}\Delta \\
\stackrel{\Delta}{0}\end{array}$ & \begin{tabular}{l}
$\frac{*}{*}$ \\
\multirow{2}{*}{} \\
$\stackrel{0}{0}$
\end{tabular} & $\begin{array}{l}\hat{\infty} \\
0 \\
0\end{array}$ & $\begin{array}{l}\text { * } \\
\stackrel{*}{\text { Oे }} \\
\stackrel{0}{0}\end{array}$ & : & $\begin{array}{l}8 \\
0 \\
0\end{array}$ & - & & & \\
\hline IX & $\begin{array}{l}n \\
\tilde{o} \\
0 \\
0\end{array}$ & 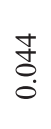 & $\begin{array}{l}\stackrel{*}{*} \\
\stackrel{0}{0} \\
\stackrel{0}{0}\end{array}$ & $\begin{array}{l}\hat{\widehat{a}} \\
0 \\
0\end{array}$ & $\begin{array}{l}\bar{\infty} \\
\stackrel{0}{0}\end{array}$ & 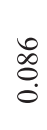 & $\begin{array}{l}n \\
0 \\
0 \\
0\end{array}$ & $\begin{array}{l}\stackrel{*}{*} \\
\stackrel{*}{\sigma} \\
\stackrel{\sigma}{0}\end{array}$ & - & & \\
\hline $\mathrm{X}$ & $\begin{array}{l}\hat{\theta} \\
0 \\
0\end{array}$ & $\begin{array}{l}\infty \\
\stackrel{0}{0} \\
\\
\end{array}$ & $\begin{array}{l}* * \\
\stackrel{*}{n} \\
\stackrel{5}{0}\end{array}$ & $\begin{array}{l}\text { ¿े } \\
\text { i. }\end{array}$ & $\begin{array}{l}\stackrel{*}{*} \\
\stackrel{4}{0} \\
\stackrel{0}{0}\end{array}$ & $\stackrel{\infty}{0}$ & $\begin{array}{l}\text { ơ } \\
0 \\
0\end{array}$ & $\begin{array}{l}\text { *. } \\
* \\
\stackrel{0}{0} \\
\\
0\end{array}$ & \begin{tabular}{l}
$*$ \\
\multirow{*}{*}{} \\
$\infty$ \\
$\infty$ \\
0 \\
0
\end{tabular} & - & \\
\hline XI & $\begin{array}{l}* \\
\stackrel{0}{0} \\
\stackrel{0}{0}\end{array}$ & $\begin{array}{l}n \\
\vdots \\
0 \\
i\end{array}$ & $\begin{array}{l}\text { * } \\
\text { ஸे } \\
\text { ஸे }\end{array}$ & $\begin{array}{l}\stackrel{*}{*} \\
\stackrel{\infty}{\infty} \\
\stackrel{0}{0}\end{array}$ & $\stackrel{\text { ô }}{0}$ & $\begin{array}{l}\infty \\
\tilde{0} \\
0\end{array}$ & $\begin{array}{l}\overline{0} \\
0 \\
0\end{array}$ & $\begin{array}{l}\stackrel{*}{*} \\
\tilde{N} \\
\tilde{0}\end{array}$ & $\begin{array}{l}\text { * } \\
\text { w } \\
\tilde{n} \\
\vdots\end{array}$ & 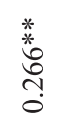 & - \\
\hline
\end{tabular}

I - Age group; II - Sex; III - Participation in another type of practice; IV - Socioeconomic class; V - Length of time practicing ballroom dancing; VI - Weekly frequency; VII Time spent per week; VIII - Physical domain; IX - Psychological domain; X - Social domain; XII - Environmental domain. 
in other activities, the age group and the length of practice.

Associations between the physical and social domains $\left(r=0.366^{* *}\right)$ and between the physical and environmental domains $\left(r=0.323^{* *}\right)$ were also observed. The psychological domain was associated with the social domain $\left(r=0.488^{* *}\right)$ and the environmental domain was also associated with the psychological domain $\left(r=0.355^{* *}\right)$ and with the social domain $\left(r=0.266^{* *}\right)$.

\section{DISCUSSION}

We believe that the reason why both sexes seek to practice ballroom dancing is that this is an activity done in couples, even though the results from the present study diverge from those of Almeida ${ }^{9}, \mathrm{D}^{\prime}$ Aquino ${ }^{10}$, Dettino ${ }^{11}$ and Schenkel et al. ${ }^{12}$, who found that women enrolled in this activity more frequently.

In relation to marital status, Costa $^{13}$ and Freitas ${ }^{14}$ also found that single individuals participated more frequently. These authors ascribed this to the possibility that ballroom dancing may present for finding a potential partner. Nonetheless, considering that the participants in the present study ranged in age from 21 to 83 years, it can be seen that ballroom dancing is sought by different age groups. The present study corroborates the findings of Toneli ${ }^{15}$, who reported that the age group with greatest representation in this activity was up to 30 years of age.

Freitas $^{14}$, Shibukawa ${ }^{16}$ and Guimarães ${ }^{17}$ also found that there was a greater concentration of participants belonging to the "middle class". This greater participation of individuals belonging to the middle class $(p=0.001)$ is believed to be because this activity is generally provided through private initiative, thus requiring a certain level of purchasing power in order to participate. The greater volume of physical activity practice among the men in the present study is in line with what was found by Pieron ${ }^{18}$ and Salles-Costa ${ }^{19}$, who affirmed that women adhere less to physical activities consisting of localized muscle strength training or team games, and emphasized that women seek more to join in individual activities that require greater fluidity of body movement, such as in dancing, yoga or Pilates. According to Freitas ${ }^{14}$, most ballroom dancing students practice it not only in regular classes but also beyond this, at dances, other practice and parties.

The activities most frequently cited by the present sample were also observed by Salles-Costa ${ }^{19}$, both among men and among women. Rocha and Almeida ${ }^{6}$ highlighted adherence to different types of activity, as also shown in the present study, noting that ballroom dancing was sought even by people who were already involved in other types of physical activities.

In relation to length of practice, the present results were congruent with those observed by Shibukawa ${ }^{16}$ and Guimarães ${ }^{17}$. The reasons that led the individuals in the present study to practice ballroom dancing were congruent with those obtained by Rocha and Almeida ${ }^{6}$, Freitas ${ }^{14}$ and Santana, Corradini and Carneiro ${ }^{20}$. According to these authors, the second motivating factor was that these individuals would acquire skills that would allow them to go to dances (19.6\%). These individuals considered that this was a form of physical activity that would contribute towards improvement of health (20.6\%). The search for improved health was also one of the main factors found by Gobbo ${ }^{21}$, while Zamoner ${ }^{22}$ highlighted that his sample started to do this activity in order to learn how to dance (48.8\%). D'Aquino ${ }^{10}$ found that $63.3 \%$ of his subjects gave reasons involving the idea that they enjoyed dancing, while in the present study, the frequency of this reason was low ( $0.8 \%$ of the men and $2.0 \%$ of the women). It was also observed that when the women expressed their reasons, only $0.2 \%$ of them referred to seeking better QoL. Among the reasons for participating, the following were also cited: getting to know other people (men $17.4 \%$, women $17.4 \%$ ), becoming professional (men 5.8\%, women $4.5 \%$ ), esthetic purposes (men $2.2 \%$, women $5 \%$ ), accompanying friends or relatives (men $2.6 \%$, women $4.5 \%$ ), self-knowledge (men 0.4 , women $0.3 \%$ ), self-expression (men $0.2 \%$ ), curiosity (men $0.2 \%$, women $0.2 \%$ ), neurological stimulation (women $0.3 \%$ ), liking to dance (men $0.8 \%$, women $2 \%$ ) and personal satisfaction (men $0.2 \%$, women $0.3 \%$ ).

Cieslak ${ }^{23}$ identified differences between the sexes in the social domain, such that women presented higher scores than men. Although no significant differences were found in the psychological and social domains, the older age groups tended to present higher scores. Taking into consideration the changes inherent to aging, which produce perceptible modifications to many characteristics, between youth and mature age, we believe that older people start to have greater awareness of these changes and are able to adapt to them with a positive attitude towards coping with them. In other words, although their physical, psychological, social and environmental condition may, objectively, no longer be excellent, their accumulated experience allows them to view these issues more acquiescently.

Zamarim $^{24}$ and Oliveira ${ }^{25}$ did not observe any significant differences in physical activity practices or QoL among the groups that they investigated, in any of the domains (physical, psychological, social and environmental). However, Cielask ${ }^{23}$ found that physical activity levels correlated significantly with the social and environmental domains and with general QoL, and found relationship trends between physical activity and the physical and psychological domains. Toscano and Oliveira ${ }^{26}$ observed that in all the domains, the results from the more active individuals were significantly superior. According to Sandel ${ }^{27}$, in relation to individuals with malignant neoplasia, the QoL results improved significantly through a dance and movement program. In the literature, improvement of QoL is significantly correlated with physical activity.

Leaving aside the abovementioned associations among the participants' characteristics, some factors resulting from ballroom dancing practice were positively associated with the QoL domains and these, in turn, also showed associations. These results suggest that, like other types of physical activity, ballroom dancing practice may favor improvement or maintenance of its participants' QoL, thereby boosting the benefits coming from a more active lifestyle, not only in its physical aspects but also in its psychological, social and environmental aspects.

\section{CONCLUSION}

Ballroom dancing is a type of physical activity practiced without distinction by both sexes. Although it is sought by individuals of different ages, it preferentially brings together younger unmarried individuals belonging to higher social classes, given that this activity requires a certain level of purchasing power in order to participate. It is an activity that is not limited to the classroom, since ballroom dancers are seen to do it in other places, like dances and parties, thus making this activity present in their lives. Moreover, ballroom dancers tend to also be involved in other types of physical activity.

The main reasons why individuals take part in this activi- 
ty relate to leisure practices, improvement or maintenance of health and acquisition of skills so that they can go to dances. These reasons tend to be sustained by a weekly periodicity of two sessions, and the majority of the participants started recently (within the past year).

Lastly, it can be concluded that ballroom dancing may constitute an instrument for improvement or maintenance of QoL, since the participants presented satisfactory scores that were above average, for all four domains. Although no cause-effect relationship could be established from the present study, it was observed that the QoL domains were associated with certain characteristics, of which the most relevant ones seemed to be participation in other activities, age group, length of practice among the participants, characteristics of the ballroom dancing practice and significant relationships among the four domains. Some factors resulting from ballroom dancing practice were positively associated with the QoL domains and these, in turn, also showed associations. Thus, like other types of physical activity, ballroom dancing practice boosts the benefits coming from a more active lifestyle, not only in its physical aspects but also in its psychological, social and environmental aspects.

\section{REFERENCES}

1. Fleck M, Lousada $F$, Xavier $M$, et al. Aplicação da versão em português do instrumento abreviado de avaliação da qualidade de vida "WHOQOL-bref" Rev. Saúde Pública 2001; 34(2):178-83.

2. Gordia AP. Associação da atividade física, consumo de álcool e índice de massa corporal com a qualidade de vida de adolescentes. Dissertação de mestrado, no departamento de educação física, setor de ciências biológicas da universidade federal do Paraná. Curitiba, 181p. 2008.

3. Coimbra MA, Vágula S, Souza VFM, Pereira VR. Estudo Comparativo Da Agilidade Entre Praticantes De Dança De Salão. Sábios: Rev. Saúde e Biol 2007;2(2):36434.

4. Guimarães ACA, Simas JPN, Farias SF. Dança Como Uma Contribuição Para A Qualidade De Vida. Cinergis 2003;4(1):34-54.

5. Abreu EV, Pereira LTZ, Kessler E J. Timidez e motivação em indivíduos praticantes de dança de salão. Revista Conexões 2008;6:21-33.

6. Rocha $M D$, Almeida $C M$. Dança de salão instrumento para a qualidade de vida. Movimento \& Percepção 2007;7(1):14-23.

7. Lorandi R M. Resposta cronotrópica na dança de salão: influência do contato físico no forró e no samba. Artigos de periódico (graduação) - Universidade do Estado de Santa Catarina, Curso de Educação Física, Florianópolis, 2008.

8. ABEP. Associação Brasileira de Empresas de Pesquisa. Critério de classificação econômica Brasil. São Paulo: ABEP. 2008.

9. Almeida R. Dança de salão uma opção de lazer, atividade física e inclusão so- cial em condomínios da Barra da Tijuca. $14^{\circ}$ ENAREL-UNISC. Santa Cruz do Sul - RS. Brasil, 2002.

10. D'Aquino R, Guimarães AC, Simas JPN. Dança de Salão: Motivos dos indivíduos que procuram esta atividade. Revista Digital Efdeportes 2005;10(88):17-23.

11. Dettino S Jr. Valores de Ligação no Comportamento de Consumo: Um estudo exploratório sobre a prática da dança de salão no Rio de Janeiro. Artigos de periódico (dissertação) - Pontifícia Universidade Católica do Rio de Janeiro Programa De Pós-Graduação em Administração Da Puc-Rio, 2008.

12. Schenkel IC, Bündchen DC, Quites MP, Santos RZ, Santos MB, et al. Comportamento da Pressão Arterial em Hipertensos após Única Sessão de Caminhada e de Dança de Salão: estudo preliminar. Rev Bras Cardiol 2011;24(1):26-32.

13. Costa CG. Silva HVP, Nunez PRM, et al. Aspectos psicossociais da prática da dança de salão em academias de Florianópolis. Cinergis 2003;4(1):165-178.

14. Freitas GA. Motivos de condução, permanência e abandono de praticantes adultos de dança de salão da cidade de Florianópolis. Artigos de periódico (graduação)-Universidade do Estado de Santa Catarina, Curso de Educação Física, Florianópolis, 2008.

15. Toneli P. Dança de salão: instrumento para a qualidade de vida no trabalho apresentado ao Instituto Municipal de Ensino Superior de Assis - IMESA/ FEMA, como requisito para obtenção do título de Bacharel em Administração. 2007.

16. Shibukawa RM, Guimarães ACA. Motivos da Prática de Dança de Salão em Escolas Particulares. Artigos de periódico (graduação)-Universidade do Estado de Santa Catarina, Curso de Educação Física, Florianópolis, 2008.

17. Ouriques I, Soares A, Guimarães ACA, Simas JPNS. Adesão e Permanência no Projeto de Dança Educacional da Secretaria Municipal de São José. Lecturas Educacíon Física y Deportes 2008;13(119)14-23.

18. Pieron M. Estilo de vida, prática de atividades físicas e esportivas, qualidade de vida. Fit Perf J 2004;3(1):11-19.

19. Salles-Costa R, Heiborn ML, Weneck GL, Faerstein E, Lopes CS. Gênero e prática de atividade física de lazer. Cad Saúde Pública 2003:19(2):23-33.

20. Santana SPS, Corradini AM, Carneiro RH. A dança de salão e seus benefícios motores, cognitivos e sociais. Anuário da produção de iniciação cientifica discente 2009;12(15):83-104.

21. Gobbo DE, Carvalho DA. Dança de salão como qualidade de vida para a terceira idade. Revista Eletrônica de Educação Física 2005;1(2):56-66.

22. Zamoner M. Prática e ensino de dança de salão, comportamento sexual e drogadição: confusões e preconceitos. Revista Digital - Efdeportes Buenos Aires 2007;12(107):32-43.

23. Cieslak F, Elsangedy HN, Krinski K, et al. Relação do nível de qualidade de vida e atividade física em acadêmicos de educação física. Fit Perf J 2007;6(6):357361.

24. Zamarim MA, Miranda MLJ, Velardi M. Influências da prática de atividades físicas em academia na qualidade de vida de adultos universitários: Um estudo comparativo 2006; 47 : 351-356

25. Oliveira HP, Gomes EB, Júnior GBV. Relação entre o nível de atividade física percepção da qualidade de vida dos carteiros em Ponta Grossa - PR. CPAqv 2009;1(2).

26. Toscano JJO, Oliveira ACC. Qualidade de Vida em Idosos com Distintos Níveis de Atividade Física. Rev Bras Med Esporte 2009;15(3):23-24.

27. Sandel SL, Landry NBS, Faria LMA, Quellette RPT, Majczak MBA. Dance and mo vement program improves quality-of-life measures in breast cancer survivors. Cancer nursing 2005;28(4):50-60. 